\title{
Chitinases of Trichoderma atroviride Induce Scab Resistance and Some Metabolic Changes in Two Cultivars of Apple
}

\author{
M. Faize, M. Malnoy, F. Dupuis, M. Chevalier, L. Parisi, and E. Chevreau
}

First, second, third, fourth, and sixth authors: Unité d'Amélioration des Espèces Fruitières et Ornementales, INRA, 42, rue Georges Morel, BP 57, 49071 Beaucouzé cedex, France; and fifth author: UMR Pathologie Végétale, INRA, 42 rue Georges Morel, BP 57, 49071 Beaucouzé cedex, France.

Current address of M. Faize: National Institute for Agro-Environmental Sciences, Kannondai 3-1-3, Tsukuba, Ibaraki 305-8604, Japan. Current address of M. Malnoy: Department of Plant Pathology, Cornell University-NYSAES, Geneva, NY 14456. Accepted for publication 30 June 2003.

\begin{abstract}
Faize, M., Malnoy, M., Dupuis, F., Chevalier, M., Parisi, L., and Chevreau, E. 2003. Chitinases of Trichoderma atroviride induce scab resistance and some metabolic changes in two cultivars of apple. Phytopathology 93:1496-1504.

This study reports the combination of a transgene-mediated defense mechanism with a conventionally bred resistance in order to improve apple scab resistance. Two cultivars of apple (Galaxy, scab-susceptible, and Ariane, carrying the $V f$ resistance gene) were transformed with endochitinase and exochitinase genes derived from the biocontrol fungus

resistance conferred by the $V f$ gene. A negative correlation between growth of transgenic lines and endochitinase activity was observed. Reduced growth appeared to be associated with high lignin content and high peroxidase as well as glucanase activity, suggesting that endochitinase activity may disturb the metabolism of the plant. Scab inoculation with races 1 and 6 performed in a growth chamber on 14 lines of normal vigor identified 6 lines with significantly enhanced resistance. Ten lines with reduced vigor were tested in vitro with a bioassay on rooted shoots. All lines expressing high endochitinase activity exhibited a significant reduction of scab symptoms.
\end{abstract} Trichoderma atroviride. The obtained transgenic lines were analyzed for the expression of both genes and resistance to two races of the pathogen Venturia inaequalis: the common race 1 and race 6 which overcomes the
Additional keywords: disease resistance, genetic engineering, Malus $\times$ domestica.
Scab is the most serious disease causing economic losses in commercial apple orchards (26). The causal agent of this disease is the fungus Venturia inaequalis, which attacks both the foliage and the fruits of apple trees. Infection of mature apples causes heavy fruit drop which results in reduced yield. Infection of leaves early in the season causes defoliation, which weakens the tree and results in poor fruit setting. In addition, the presence of brownish black spots and disfigured fruits causes customer rejection. The epidemic spread of this disease is routinely controlled by the application of agrochemicals. However, chemicals are costly and tend to become less efficient due to the evolution of resistance among the pathogens. In addition, their persistence in the soil can be harmful to the environment (19). Genetic improvement of scab tolerance by conventional crossbreeding is underway in several countries, but it is a time-consuming process and the new-bred cultivars have not received wide commercial acceptance. Furthermore, in Europe, new races of $V$. inaequalis have overcome the $V f$ gene $(32,34,38)$, which is the main source of scab resistance used in apple breeding (21). Genetic dissection of partial scab resistance by quantitative trait loci (QTL) mapping has been undertaken in the frame of a European project (D.A.R.E. [Durable Apple Resistance in Europe]), with the final aim of pyramiding major genes and QTLs to build a durable resistance (22). Genetic engineering offers a new alternative for cultivar improvement. Already, several groups have attempted to improve highly susceptible apple cultivars such as Gala (45), Jonagold (8), and MacIntosh $(2,3)$ by the integration of antifungal genes. However,

Corresponding author: E. Chevreau; E-mail address: chevreau@angers.inra.fr

Publication no. P-2003-0926-01R

(C) 2003 The American Phytopathological Society the use of a transgenic defense mechanism in addition to natural resistance conferred by the $V f$ gene in order to protect apple against $V$. inaequalis strains of various virulence has never been reported.

The most widely used transgenic approach to increase plant resistance to fungi has been to overexpress hydrolytic enzymes such as glucanases and chitinases, which belong to pathogenesis-related (PR) proteins (7) and exhibit in vitro antifungal activity. Because chitin is the major component of the cell wall of many fungi, the overexpression of these enzymes in plant cells leads to hyphal lysis, resulting in a decrease of fungal growth. Several plant species have been transformed with transgenes encoding different types of hydrolytic enzymes and have presented a reduction in size and number of lesions upon challenge by various fungal pathogens (review in literature citation 37).

The biocontrol fungus Trichoderma atroviride (previously $T$. harzianum) produces many chitinolytic enzymes, including endochitinase, which randomly cleaves chitin. Trichoderma endochitinase encoded by gene ech42 appears to be more effective in controlling fungi than chitinases found in plants $(14,23)$. This enzyme inhibits spore germination and hyphal elongation. For this reason, several plant species expressing the ech 42 gene have been generated. Transgenic grapevine transformed with this gene reduced the growth of Botrytis cinerea (18). Similarly, potato and tobacco expressing this gene exhibited a high level and a broad range of resistance against foliar and soilborne pathogens (25). Transgenic broccoli expressing this gene showed limited resistance to Alternaria brassicola and Sclerotinia sclerotiorum (30). Bolar et al. (3) obtained several lines of very susceptible 'McIntosh' apple with varying levels of ech42 expression. Some of them exhibited increased tolerance to $V$. inaequalis. However, transgenic lines with high endochitinase activity had a reduced vigor. The possibility that chitinolytic enzymes are involved in various plant develop- 
ment processes is being elucidated $(35,40)$. Recently, tomato plants transformed with an endochitinase and a chitobiosidase gene from Streptomyces albidoflavus expressed reduced plant height, early flowering, and enhanced fruit production (11).

Endochitinase of $e c h 42$ gene interacts synergistically with other chitinolytic enzymes of $T$. atroviride such as $N$-acetyl- $\beta$-glucosaminidase (exochitinase). Exochitinase hydrolyses the terminal nonreducing $N$-acetyl- $\beta$-glucosamine residue from chitibiose or its analogues. Several studies have shown that in vitro combinations of these enzymes, even at low levels, are more effective than a single one against fungal pathogens $(14,24)$. Recently, Bolar et al. (2) studied transgenic lines of MacIntosh expressing endochitinase of ech 42 gene and exochitinase of nag70 gene alone or combined and demonstrated in planta synergy between both enzymes.

The objective of this study was to explore the combination of transgene-mediated defense mechanisms (ech42 plus nag70) with a conventionally bred natural resistance $(V f)$ and to study its ability to protect apple from strains of $V$. inaequalis carrying different virulences. Transgenic lines of two genotypes were studied: Galaxy, which is highly scab-susceptible, and Ariane, a newly bred hybrid carrying the $V f$ gene. Levels of transgene expression, incidence on plant vigor, metabolism, and scab resistance were studied.

\section{MATERIALS AND METHODS}

Plant, bacterial, and fungal materials. Two genotypes were used. Galaxy, a spontaneous mutant of cv. Gala, was selected in New Zealand for its earliness and darker fruit color (42), and is highly scab-susceptible. Ariane is a hybrid from the apple breeding program of the Institut National de la Recherche Agronomique (INRA, Angers), of complex parentage, carrying the $V f$ gene from Malus floribunda 821 conferring resistance to race 1 of $V$. inaequalis.

The plasmid pBIN (Endo+Nag) was used for transformation of these genotypes (Fig. 1). It carries the cDNA of both ech42 and nag70 genes of T. atroviride under the control of enhanced Cauliflower mosaic virus (CaMV)-35S promoter with the Alfalfa mosaic virus (AMV) leader sequence (2). This plasmid was transformed into the super-virulent Agrobacterium tumefaciens strain EHA105 (15).

For scab inoculation, two monoconidial strains of $V$. inaequalis were used: strain 104, which is the race 1 reference strain (34) and strain EU-D-42, which is a race 6 strain recently isolated and characterized in the frame of the D.A.R.E. project (L. Parisi, unpublished data).

Plant transformation, rooting, and acclimatization. Leaves from in vitro shoots of Galaxy and Ariane (1,483 and 1,077 leaves, respectively, in four separate experiments) were inoculated with Agrobacterium tumefaciens EHA105 pBIN (Endo+Nag) according to the procedure published by Norelli et al. (31). Transgenic shoots were recovered under a selection pressure of $100 \mathrm{mg}$ of kanamycin per liter. All transgenic lines were rooted by auxin treatment (indolebutyric acid [3 $\left.\mathrm{mg} \mathrm{liter}^{-1}\right]$ or naphthaleneacetic acid [0.5 $\left.\mathrm{mg} \mathrm{liter}^{-1}\right]$ for 10 days) followed by transfer to hormonefree medium. Acclimatization was performed in a peat/perlite mixture by progressively decreasing the relative humidity. Rooting percent ( 3 weeks after auxin induction) and plant height ( 8 weeks after acclimatization) were recorded for each transgenic line.

Ploidy level. Ploidy level of transgenic lines and controls was estimated by flow cytometry. Nuclei were isolated from in vitro leaves by manual chopping with a razor blade, added to buffer, following the method of Brown et al. (5), containing 2\% (vol/vol) 4,6-diamino-2-phenyl-indole dihydrochloride (Cheminex), filtered through $20-\mu \mathrm{m}$ nylon mesh, and analyzed with a cytometer (Cell Analyzer II; Partec, Münster, Germany). Pea leaf nuclei were used as internal reference.

Polymerase chain reaction and reverse transcription-polymerase chain reaction analyses. DNA was extracted from $20 \mathrm{mg}$ of young leaves excised from acclimatized plants as described by Doyle and Doyle (9). Putatively transformed lines were screened by polymerase chain reaction (PCR) for the presence of ech42 or nag70 genes. The reactions contained $10 \mathrm{mM}$ Tris- $\mathrm{HCl}, \mathrm{pH} 8.8$, $1.5 \mathrm{mM} \mathrm{MgCl} 2,50 \mathrm{mM} \mathrm{KCl}, 0.1 \%$ (vol/vol) Triton X-100, $50 \mu \mathrm{M}$ each dNTP, 0.2 units of Taq DNA polymerase, $100 \mathrm{ng}$ of DNA, and $0.2 \mu \mathrm{M}$ each primer. The reaction mixtures were taken through 35 cycles of $95^{\circ} \mathrm{C}$ for $1 \mathrm{~min}, 50^{\circ} \mathrm{C}$ annealing for $n a g 70$ and $54^{\circ} \mathrm{C}$ for ech 42 for $1 \mathrm{~min}, 72^{\circ} \mathrm{C}$ extension for $1 \mathrm{~min}$ followed by a final extension at $72^{\circ} \mathrm{C}$ for $15 \mathrm{~min}$. For the ech 42 gene, forward primer (5'-GCCAGTGGATACGCAAACGC-3') and reverse primer (5'-CTCTAGTTGAGACCGCTTC-3') were expected to amplify a 1,000-bp fragment. For the nag70 gene, forward primer (5'-GCTCTAGACCGCCTCGGTCGTCCATCAT-3') and reverse primer (5'-CGGGATCCTTATGCGAACAAGGTGCAAGCCGTA$3^{\prime}$ ) were expected to amplify a 700-bp fragment.

For RNA extraction, $200 \mathrm{mg}$ of leaves excised from acclimatized plants was ground in liquid nitrogen. The powder was added with $1 \mathrm{ml}$ of lysis buffer $(10 \mathrm{mM}$ Tris- $\mathrm{HCl}, \mathrm{pH} 7.5,50 \mathrm{mM}$ $\mathrm{MgCl}_{2}$, and $5 \%$ [wt/vol] sodium dodecyl sulfate [SDS]), and the homogenate was incubated for $10 \mathrm{~min}$ at $60^{\circ} \mathrm{C}$ and then treated with $250 \mu \mathrm{l}$ of potassium acetate $(3 \mathrm{M}, \mathrm{pH} 5)$. After centrifugation for $10 \mathrm{~min}$ (all centrifugations were performed at $15,000 \times g$ at $4^{\circ} \mathrm{C}$ ), 1 volume of isopropanol was added to the supernatant, and the tube was incubated in ice for $15 \mathrm{~min}$ followed by a second centrifugation for $30 \mathrm{~min}$. The pellet was dissolved in $100 \mu \mathrm{l}$ of RNase-free water, supplemented by $20 \mu \mathrm{l}$ of $100 \%$ ethanol, and incubated for $15 \mathrm{~min}$ in ice. After a third centrifugation for $10 \mathrm{~min}$, the supernatant was collected and total RNA was precipitated by adding $40 \mu \mathrm{l}$ of $10 \mathrm{M} \mathrm{LiCl}$ and incubating for $2 \mathrm{~h}$ at $-20^{\circ} \mathrm{C}$. After centrifugation for $30 \mathrm{~min}$, the pellet was washed with $3 \mathrm{M} \mathrm{LiCl}$ and $80 \%$ ethanol, successively. The dried pellet was dissolved in water and treated with RNase-free DNase. After phenol-chloroform (1/1) and chloroform (1/1) washes, total RNA was precipitated after overnight incubation at $-20^{\circ} \mathrm{C}$ with 2 volumes of $100 \%$ ethanol and 0.5 volume of $7.5 \mathrm{M}$ ammonium acetate. After a final centrifugation for $30 \mathrm{~min}$, the pellet was washed with $80 \%$ ethanol, dried, and dissolved in RNase-free water.

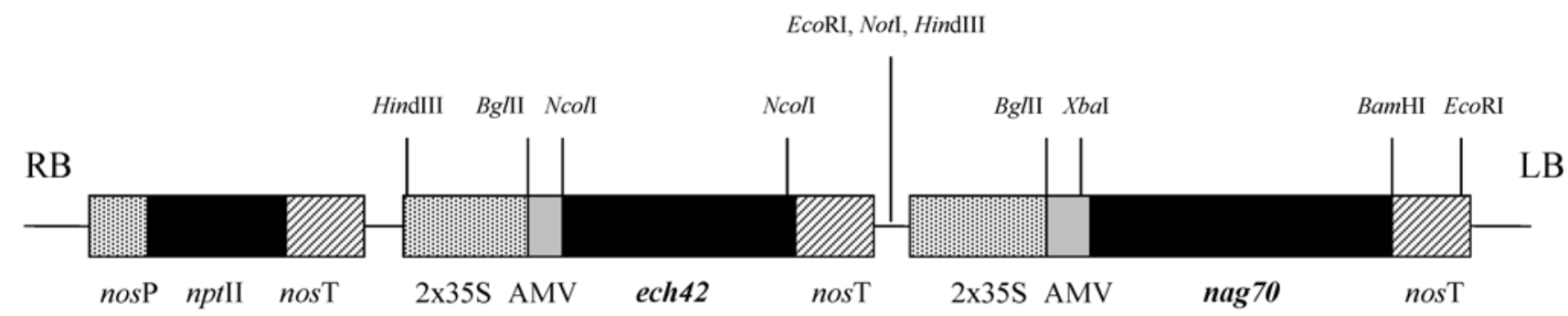

Fig. 1. T-DNA of plasmid pBIN (Endo+Nag) containing the cDNA of ech42 and nag70. nosP, nos promoter; nosT, nos terminator; nptII, neomycin phosphotransferase II gene; 2x35S, enhanced Cauliflower mosaic virus $35 \mathrm{~S}$ promoter; AMV, Alfalfa mosaic virus leader sequence; RB, right border; and LB, left border. 
Expression of ech42 and nag70 genes was studied by reverse transcription (RT)-PCR. cDNA was synthesized by Moloney murine leukemia virus (M-MLV) reverse transcriptase (Promega Biosciences, San Luis Obispo, CA) and used later for PCR amplification. Initial amounts of PCR products were adjusted for each line on the basis of an equivalent amplification of cDNA encoding the $\alpha$ subunit of translation elongation factor 1 (ef1- $\alpha$ ), a member of a constitutively expressed gene family (27). In order to evaluate differences among clones, the amplification was limited to 30 cycles. First, efl- $\alpha$ PCR was carried out with degenerated primers (forward, 5'-ATTGTGGTCATTGGYCAYGT-3' and reverse, 5'CCTATCTTGTAVACATCCTG-3') designed from multiple sequence alignments (39). In a second reaction, comparative amplification was carried out with ech42 or nag70 primers on equivalent total cDNA. The intensity of signals was quantified with the software Gel Analyst-Clara Vision (Orsay, France), and the ratios ech42/efl- $\alpha$ and nag70/efl- $\alpha$ were calculated. This experiment was performed at least twice and one representative result is shown.

Plant enzymatic activities and lignin-deposition assays. For plant enzymatic activities, all centrifugations were performed at $4^{\circ} \mathrm{C}$. Exochitinase activity was measured according to the procedure of Jefferson et al. (17), using a specific substrate, 4-methylumbelliferyl- $\beta$-D-glucosaminide (Sigma Chemical, St. Louis). Twenty milligrams of leaf tissue from greenhouse-grown plants was ground in liquid nitrogen and extracted in $0.5 \mathrm{ml}$ of buffer (40 mM sodium acetate, $\mathrm{pH}$ 5.0, $4 \mathrm{mM} \mathrm{Na}{ }_{2}$ EDTA, 0.08\% [wt/vol] SDS, $0.08 \%$ [vol/vol] Triton X-100, and $10 \mathrm{mM} \beta$-mercaptoethanol) containing 1/4-strength methanol (vol/vol). After centrifugation for $15 \mathrm{~min}$ at $13,000 \times g, 150 \mu \mathrm{l}$ of the supernatant was added to a solution containing $200 \mu \mathrm{l}$ of the substrate $(4 \mathrm{mM})$ and $350 \mu \mathrm{l}$ of extraction buffer. For each sample, a $200-\mu \mathrm{l}$ aliquot was removed immediately and added to $800 \mu \mathrm{l}$ of $0.2 \mathrm{M} \mathrm{Na}_{2} \mathrm{CO}_{3}$ (stop buffer) to be used as control. The remaining mixture was incubated at $37^{\circ} \mathrm{C}$ for $60 \mathrm{~min}$ and then added with stop buffer. The amount of 4-methyl-umbelliferone (MU) product was determined with a fluorometer (DyNaQuant 200; Hoefer Scientific Instruments, San Francisco, CA). Exochitinase activity was normalized to the protein content of leaf homogenates determined with Coomassie blue reagent and bovine serum albumin (BSA) as a standard (4). Four to nine replicate measurements were obtained per transgenic line in several independent experiments.

Endochitinase activity was determined by the protocol of Wirth and Wolf (44) with slight modifications. One hundred milligrams of leaf tissue from greenhouse-grown plants was ground in liquid nitrogen. The powder was transferred into microfuge tubes containing $1 \mathrm{ml}$ of extraction buffer (50 mM Na-acetate, $\mathrm{pH} 5.0,2 \mathrm{mM}$ dithiothreitol, $1 \mathrm{mM}$ phenylmethylsulfonyl fluoride [PMSF], and $14 \mathrm{mM} \beta$-mercaptoethanol). After centrifugation at $16,000 \times g$ for $30 \mathrm{~min}, 100 \mu \mathrm{l}$ of the supernatant was added to $500 \mu \mathrm{l}$ of $0.2 \mathrm{M}$ Na-acetate buffer, $\mathrm{pH} 5.0$, and $200 \mu \mathrm{l}$ of the substrate CM-Chitin RBV (2 mg ml$^{-1}$ ) (Loewe Biochemical, Sauerlach, Germany). The mixture was incubated at $37^{\circ} \mathrm{C}$ for $60 \mathrm{~min}$, and the reaction was stopped by adding $250 \mu \mathrm{l}$ of $2 \mathrm{~N} \mathrm{HCl}$. Controls consisted of the same mixture, except that the reaction was stopped immediately after the substrate was added. Intact chitin was precipitated after $10 \mathrm{~min}$ of incubation in ice and then separated from the digested chitin by centrifugation at $10,000 \times g$ for $10 \mathrm{~min}$. Endochitinase activity was determined by measuring the absorbance of the supernatant at $550 \mathrm{~nm}$ and was expressed in units per milligram of protein. Four to fourteen replicate measurements were obtained per transgenic line in several independent experiments.

To assay for peroxidase (POD) and glucanase (GLU) activities, $100 \mathrm{mg}$ of leaf tissue from greenhouse-grown plants was ground in $50 \mathrm{mM}$ phosphate buffer, $\mathrm{pH} 7.5$, containing $0.01 \%$ ( vol/vol) Triton X-100, $14 \mathrm{mM} \beta$-mercaptoethanol, $1 \mathrm{mM} \mathrm{PMSF}$, and 8\% (wt/vol) polyvinylpolypyrrolidone. The homogenate was centrifuged at $16,000 \times g$ for $20 \mathrm{~min}$, and the supernatant was assayed for POD (29) and GLU activity (44). These experiments were repeated twice (four replicates).

Lignin-deposition assays were performed independently at least three times by the phloroglucinol method described by Gurr (13). Plants were cleared in methanol for $1 \mathrm{~h}$, exposed to $1 \%(\mathrm{wt} / \mathrm{vol})$ phloroglucinol for $2 \mathrm{~h}$, and then exposed to $6 \mathrm{~N} \mathrm{HCl}$ until a red color developed, indicating lignin deposition. The level of lignin deposition was qualitatively evaluated using nontransgenic Ariane as negative control. Similar trends in lignin deposition were observed between experiments. One representative replicate is presented.

Western blot analysis. Proteins were extracted according to the protocol described by Shuster and Davies (41) with slight modifications. One hundred milligrams of leaf tissue from greenhousegrown plants was ground in liquid nitrogen and transferred to $0.5 \mathrm{ml}$ of the homogenization buffer $(0.5 \mathrm{M}$ Tris- $\mathrm{HCl}, \mathrm{pH} 8.7$, $0.7 \mathrm{M}$ sucrose, $0.05 \mathrm{M} \mathrm{Na}_{2}$ EDTA, $0.1 \mathrm{M} \mathrm{KCl}, 14 \mathrm{mM} \beta$-mercaptoethanol, and $1 \mathrm{mM}$ PMSF). Five hundred microliters of phenol was added, and the mixture was incubated on ice for $10 \mathrm{~min}$. After centrifugation at $6,000 \times g$ for $10 \mathrm{~min}$, the upper phase was collected and 1 volume of homogenization buffer was added. After a second centrifugation in the same conditions, the upper phase was collected and precipitated with ammonium acetate $(0.1 \mathrm{M}$ prepared in methanol) overnight at $-20^{\circ} \mathrm{C}$. After centrifugation at $10,000 \times g$ for $30 \mathrm{~min}$, the pellet was washed twice with acetone containing $0.07 \%$ ( $\mathrm{vol} / \mathrm{vol}$ ) of $\beta$-mercaptoethanol, dried, and dissolved in $200 \mu \mathrm{l}$ of Tris- $\mathrm{HCl}, \mathrm{pH} 8.8$, containing $14 \mathrm{mM} \beta$ mercaptoethanol, $5 \mathrm{mM} \mathrm{Na} 2$ EDTA, and $500 \mathrm{mM}$ sucrose.

SDS-polyacrylamide gel electrophoresis was carried out in a $12 \%$ (wt/vol) polyacrylamide gel, prepared according to Laemmli (20) and run on a Mighty Small II Electrophoresis apparatus (Hoefer Scientific Instruments). Western blotting to nitrocellulose enhanced chemiluminescence (ECL) membrane (Amersham Biosciences, Piscataway, NJ) was carried out under semidry conditions. The membrane was blocked by $10 \%$ (wt/vol) skimmed milk in phosphate saline buffer $\left(80 \mathrm{mM} \mathrm{Na} \mathrm{HPO}_{4}, 20 \mathrm{mM}\right.$ $\mathrm{NaH}_{2} \mathrm{PO}_{4} \cdot 2 \mathrm{H}_{2} \mathrm{O}$, and $\left.100 \mathrm{mM} \mathrm{NaCl}, \mathrm{pH} 7.5\right)$ for $1 \mathrm{~h}$ at $37^{\circ} \mathrm{C}$ and washed three times in the same buffer containing $0.01 \%$ ( $\mathrm{vol} / \mathrm{vol}$ ) Tween 20 . The membrane was then incubated with antibody antiech42 $(1 / 3,000)$ (provided by G. E. Harman) for $2 \mathrm{~h}$, washed three times, incubated with the secondary antibody horseradish peroxidase conjugate, washed again, and stained with ECL reagent. Signals were detected on X-ray film.

Evaluation of apple scab resistance. For disease assessment on acclimatized plants, nine transgenic lines from Galaxy and five from Ariane were selected for their normal vigor. Nontransgenic Galaxy and Ariane were used as controls. The youngest leaf of actively growing shoots was tagged, and the plants were inoculated with a conidial suspension $\left(1.25 \times 10^{5}\right.$ conidia $\left.\mathrm{ml}^{-1}\right)$ of strain 104 or EU-D-42 of $V$. inaequalis, as described by Parisi and Lespinasse (33). Symptoms were recorded 12 to 14 days after inoculation on four leaves per shoot (tagged leaf, immediate upper, and two lower leaves). The type of symptoms was scored using the 6 class-scale of Chevalier et al. (6). The incidence of the disease was recorded as the percentage of scabbed leaves, and the severity was evaluated by the percentage of leaf area with sporulating lesions, recorded on a 7 class-scale as described by Parisi et al. (32). The bioassay described previously was not suitable to evaluate apple scab resistance of transgenic lines with a reduced vigor in greenhouse, although in vitro shoots of these lines did not show any significant difference of growth when compared with the nontransgenic lines. Therefore, we chose to use another bioassay adapted from the method described by Guillaumès et al. (12), based on the inoculation of rooted in vitro shoots. Briefly, agar in pots containing the rooted shoots was amended with a thin layer of the following mixture: penicillin $\left(125 \mu \mathrm{g} \mathrm{ml}^{-1}\right)$, streptomycin $\left(250 \mu \mathrm{g} \mathrm{ml}^{-1}\right)$, aureomycin $\left(50 \mu \mathrm{g} \mathrm{ml}^{-1}\right)$, and the fungicide captan $\left(5 \mathrm{mg} \mathrm{ml}^{-1}\right)$, in order to avoid microbial contamination. Shoots were then sprayed with a sterile conidial suspension $(1.5 \times$ 
$10^{5}$ spore $\mathrm{ml}^{-1}$ ) prepared as described by Bénaouf and Parisi (1) and incubated in a growth chamber (temperature $17^{\circ} \mathrm{C}$, photoperiod $18 \mathrm{~h}$ ) for 3 weeks. Symptoms were recorded as described previously.

In both bioassays, for each line-strain interaction, a susceptibility index was calculated as the product of incidence by severity. Data were subjected to statistical analysis (analysis of variance and Dunnett test) using the SAS/STAT 6.06 software (SAS Institute, Cary, NC).

\section{RESULTS}

Recovery of transgenic lines harboring ech42 and nag70 genes. Transformation rates averaged 1.4 and $2.0 \%$ for genotypes Galaxy and Ariane, respectively. In total, 21 lines of Galaxy and 22 lines of Ariane were regenerated under kanamycin selection. Ploidy level determined by flow cytometry revealed two tetraploid lines among Ariane transgenic lines (Table 1). All diploid lines were checked for the presence of the ech 42 and nag70 genes by PCR analysis using their corresponding primers. Conversely to their parental lines, specific fragments of the expected size (700 bp for $n a g 70$ and 1,000 bp for ech42) were amplified from the genomic DNA extracted from all transgenic lines, except two lines (36-3 and 31-41) in which only the fragment corresponding to the ech42 gene was detected, and one line (31-46) which lacked both ech42 and nag70 genes.

Quantification of endochitinase and exochitinase activities in transgenic lines. The activity of endochitinase measured in the

TABLE 1. Recovery of transgenic lines expressing ech 42 and nag 70 genes

\begin{tabular}{lccccc}
\hline & $\begin{array}{c}\text { No. of } \\
\text { inoculated } \\
\text { leaves }\end{array}$ & $\begin{array}{c}\text { No. of } \\
\text { kanamycin- } \\
\text { resistant lines }\end{array}$ & $\begin{array}{c}\text { No. of } \\
\text { 4n lines }\end{array}$ & $\begin{array}{c}\text { No. of PCR } \\
\text { positive lines for }\end{array}$ \\
\hline Galaxy & 1,483 & 21 & 0 & 21 & ech42 \\
Ariane & 1,077 & 22 & 2 & 19 & 17 \\
\hline
\end{tabular}

nontransgenic Galaxy and Ariane genotypes was similar (about 90 units per $\mathrm{mg}$ of proteins). The activity of exochitinase also was similar in the two genotypes (about $10 \mathrm{nM}$ of MU/min/mg proteins). Among the transgenic lines analyzed, results distinguished three groups of lines (Tables 2 and 3): (i) lines exhibiting endochitinase and exochitinase activities significantly higher than the nontransgenic control (15 and 37\% of transgenic lines Galaxy and Ariane, respectively), (ii) lines exhibiting only higher endochitinase activity (30\% for Galaxy and 53\% for Ariane), and (iii) lines with a weak activity of the two enzymes, not significantly different from the controls (55\% for Galaxy and 10\% for Ariane). However, no transgenic lines exhibited only a high exochitinase activity, irrespective of the genotype.

Detection of ech42 protein in transgenic lines. In order to confirm the results of endochitinase activity, the accumulation of ech42 protein was examined by western blot analysis with antiserum raised against ech42 (Fig. 2). A representative sample of lines with high and low activities is presented. One specific band of $42 \mathrm{kDa}$, matching with the molecular mass of the ech42 protein, was detected in the lines expressing the higher endochitinase activity. Other additional smaller bands also were detected in several lines; they may result from a degradation of the ech 42 protein. The 42-kDa signal was not observed in the extracts of nontransgenic lines or transgenic lines in which the endochitinase activity was not significantly different from the control. When the concentration of loaded proteins was increased (four times higher than that in the standard experiment), ech42 signal became visible in three lines (34-3, 28-1, and 31-54) (data not shown).

Transcription of ech 42 and $n a g 70$ genes in transgenic lines. To investigate whether the absence of a significant increase of the two enzymatic activities in some transgenic lines was due to the lack of gene transcription in apple, RT-PCR was conducted (Fig. $3)$. This technique compared the level of transcription of the two transgenes and a constitutive endogenous gene efl- $\alpha$. No amplification was observed in the nontransgenic controls. In transgenic lines, neither ech42 nor nag70 gene was detected by PCR when the RNA samples were not retrotranscribed (data not shown),

TABLE 2. Endo- and exochitinase activities, height, and scab susceptibility of transgenic Galaxy lines ${ }^{\mathrm{a}}$

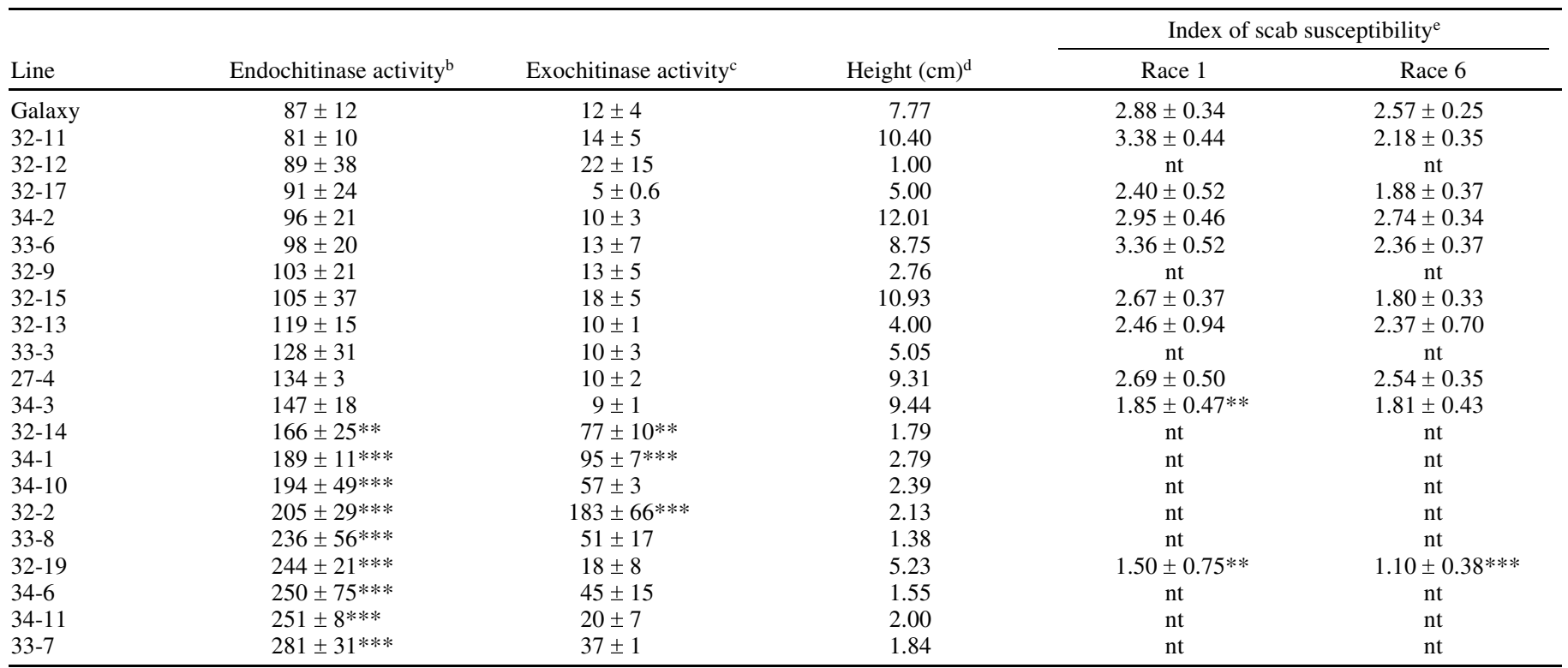

a Transgenic lines significantly different from the control at $P<0.05(*), P<0.01(* *)$, and $P<0.001(* * *)$ according to Dunnett's test.

${ }^{\mathrm{b}}$ Endochitinase activity of greenhouse-grown plants measured by change in absorbance at $550 \mathrm{~nm}$ using CM-Chitin-RBV as substrate and expressed as units per milligram of protein. Results are the mean of 4 to 14 replicates \pm confidence interval at $\alpha=5 \%$.

${ }^{c}$ Exochitinase activity of greenhouse-grown plants expressed as manomolar of 4-methyl-umbelliferone per minute per milligram of protein. Results are the mean of four to nine replicates \pm confidence interval at $\alpha=5 \%$.

${ }^{\mathrm{d}}$ Height of greenhouse-grown plants recorded 8 weeks after acclimatization.

${ }^{\mathrm{e}}$ Index of susceptibility of greenhouse plants inoculated with race 1 or race 6 of Venturia inaequalis. Data presented are the mean of 22 shoots per line on average, tested in two to four separate experiments \pm confidence interval at $\alpha=5 \%$. nt indicates not tested for scab susceptibility because of their reduced growth. 
indicating that ech42 and nag70 amplification was not due to DNA contamination. In some transgenic lines (33-6 for Galaxy and 31-29 for Ariane), neither ech42 nor nag70 gene was transcribed, indicating that the lack of increase of enzymatic activities was clearly due to the absence of gene transcription. A significantly positive correlation $(R=0.78 ; P<0.01)$ was observed between endochitinase activities and RT-PCR ech42/efl- $\alpha$ ratios (data not shown). Exochitinase results also were positively correlated, with the exception of line 31-49, in which the transcription level of nag70 gene appeared much higher than its enzymatic activity.

Phenotypical and other biochemical analyses. No particular phenotype was detected during the micropropagation of all transgenic lines. The percentage of rooting was about $60 \%$ and was not significantly different from that observed in the nontransgenic lines (data not shown). However, after acclimatization of the rooted plants in greenhouse, important differences in growth were observed. The measures of plant height 2 months after acclimatization indicated the absence of growth of about $50 \%$ of the obtained transgenic lines. This inhibition lasted the entire season of growth. No significant correlation was detected between exochitinase activity and growth, whereas a significant negative correlation $(R=-0.66 ; P<0.01)$ was detected between endochitinase activity and plant height (Fig. 4). In addition, two lines (32-9 and 32-12) that failed to express high ech42 activity exhibited a weak vigor, indicating a possible somaclonal variation due to the regeneration or transformation events.

In order to determine if reduced growth of transgenic lines was linked to a modification of their metabolism, 10 lines of Ariane

TABLE 3. Endo- and exochitinase activities, growth, and scab susceptibility of transgenic Ariane lines ${ }^{\mathrm{a}}$

\begin{tabular}{|c|c|c|c|c|c|}
\hline \multirow[b]{2}{*}{ Line } & \multirow[b]{2}{*}{ Endochitinase activity ${ }^{b}$} & \multirow[b]{2}{*}{ Exochitinase activity $^{c}$} & \multirow[b]{2}{*}{ Height $(\mathrm{cm})^{\mathrm{d}}$} & \multicolumn{2}{|c|}{ Index of scab susceptibility (race 6) } \\
\hline & & & & Acclimatized plants $\mathrm{e}$ & Rooted in vitro shoots ${ }^{\mathrm{f}}$ \\
\hline Ariane & $92 \pm 8$ & $9 \pm 3$ & 7.76 & $3.97 \pm 0.26$ & $1.89 \pm 0.20$ \\
\hline $31-29$ & $124 \pm 29$ & $10 \pm 1$ & 5.05 & $2.93 \pm 0.34 * * *$ & $1.00 \pm 0.60$ \\
\hline $31-42$ & $128 \pm 23$ & $12 \pm 9$ & 3.73 & $3.87 \pm 0.58$ & $1.62 \pm 0.45$ \\
\hline $31-54$ & $149 \pm 27 * *$ & $11 \pm 1$ & 2.11 & $2.07 \pm 0.78 * * *$ & nt \\
\hline $28-1$ & $158 \pm 20 * *$ & $43 \pm 13$ & 3.75 & $2.95 \pm 0.51^{*}$ & $\mathrm{nt}$ \\
\hline $31-28$ & $178 \pm 9^{*}$ & $10 \pm 3$ & 0.93 & nt & nt \\
\hline $31-49$ & $191 \pm 25 * * *$ & $19 \pm 11$ & 2.20 & $\mathrm{nt}$ & $0.42 \pm 0.28 * * *$ \\
\hline $31-35$ & $191 \pm 40 * * *$ & $77 \pm 30 * * *$ & 1.30 & nt & $1.36 \pm 0.14^{* *}$ \\
\hline $31-40$ & $193 \pm 44 * * *$ & $41 \pm 20$ & 1.82 & nt & $0.53 \pm 0.47 * * *$ \\
\hline $20-7$ & $204 \pm 39 * * *$ & $33 \pm 6$ & 1.17 & $\mathrm{nt}$ & nt \\
\hline $31-27$ & $210 \pm 34 * * *$ & $106 \pm 5^{* * *}$ & 1.12 & nt & $\mathrm{nt}$ \\
\hline $31-43$ & $212 \pm 31 * * *$ & $19 \pm 7$ & 1.20 & nt & nt \\
\hline $31-41$ & $214 \pm 8 * * *$ & $74 \pm 3 * * *$ & 1.66 & $\mathrm{nt}$ & $\mathrm{nt}$ \\
\hline $20-5$ & $228 \pm 18 * * *$ & $6 \pm 1$ & 0.86 & $\mathrm{nt}$ & nt \\
\hline $36-3$ & $240 \pm 52 * * *$ & $21 \pm 16$ & 3.93 & $0.87 \pm 0.31 * * *$ & $0.49 \pm 0.26^{* * *}$ \\
\hline $36-1$ & $244 \pm 8 * * *$ & $79 \pm 15 * * *$ & 1.28 & $\mathrm{nt}$ & $0.65 \pm 0.45^{* * * *}$ \\
\hline $28-11$ & $248 \pm 61 * * *$ & $239 \pm 32 * * *$ & 1.57 & nt & $0.54 \pm 0.34 * * *$ \\
\hline $31-9$ & $259 \pm 11 * * *$ & $74 \pm 30 * * *$ & 1.52 & $\mathrm{nt}$ & $0.30 \pm 0.16^{* * *}$ \\
\hline $31-56$ & $260 \pm 63^{* * *}$ & $131 \pm 7 * * *$ & 1.23 & $\mathrm{nt}$ & $0.46 \pm 0.21 * * *$ \\
\hline $28-8$ & $292 \pm 93 * * *$ & $8 \pm 5$ & 1.28 & $\mathrm{nt}$ & nt \\
\hline
\end{tabular}

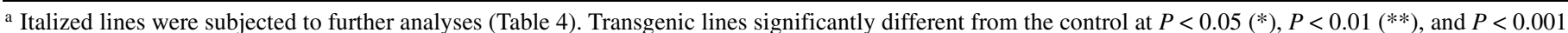
(***) according to Dunnett's test. nt indicates not tested for scab susceptibility because of their reduced growth.

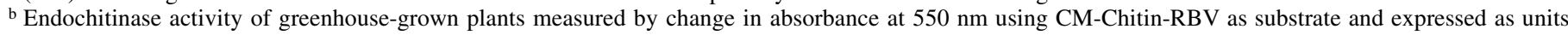
per milligram of protein. Results are the mean of four to nine replicates \pm confidence interval at $\alpha=5 \%$.

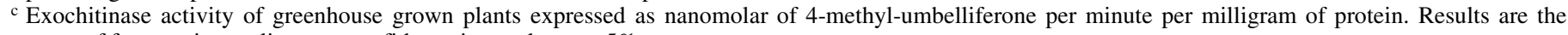
mean of four to nine replicates \pm confidence interval at $\alpha=5 \%$.

${ }^{\mathrm{d}}$ Height of greenhouse-grown plants recorded 8 weeks after acclimatization.

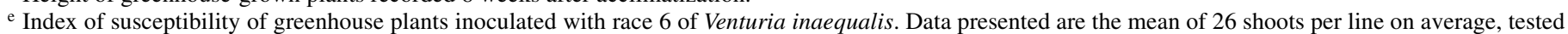
in two separate experiments \pm confidence interval at $\alpha=5 \%$.

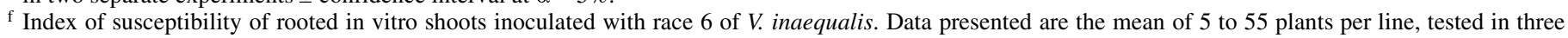
separate experiments \pm confidence interval at $\alpha=5 \%$.
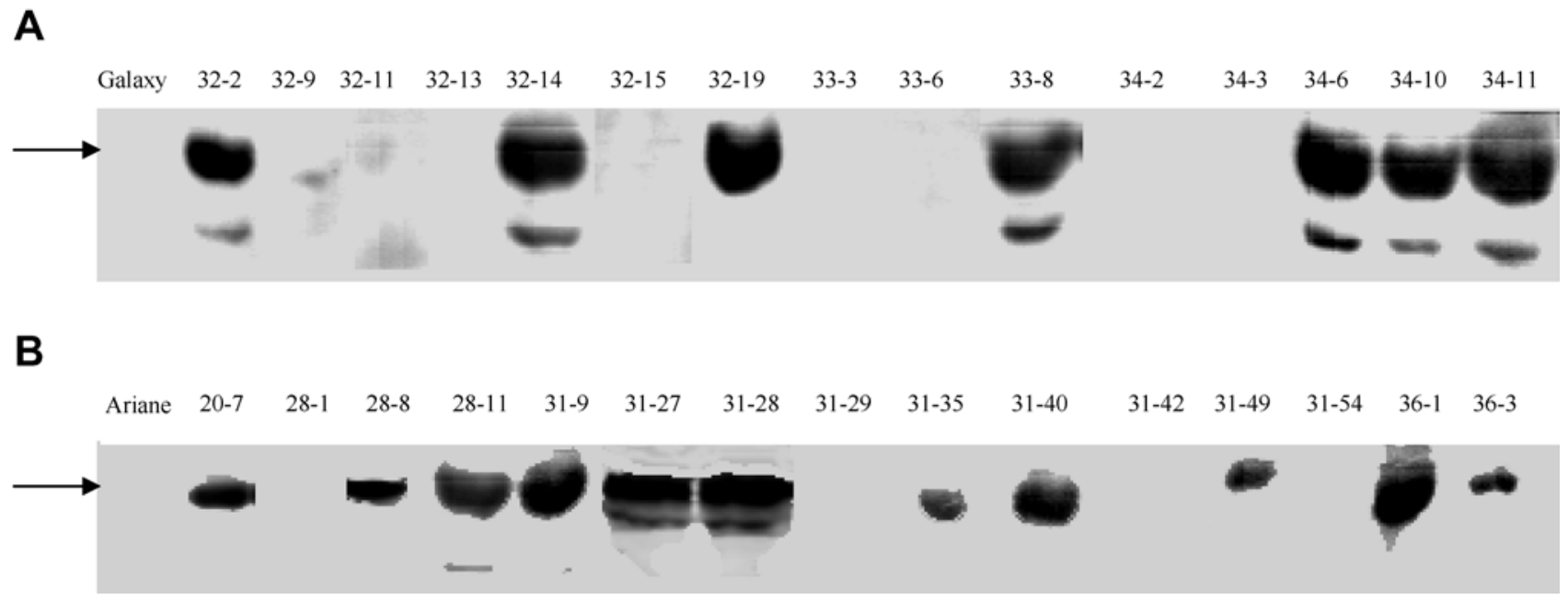

Fig. 2. Detection of endochitinase by western blot analysis of leaf extracts from a sample of transgenic lines and nontransgenic $\mathbf{A}$, Galaxy and $\mathbf{B}$, Ariane. A total of $2.5 \mu \mathrm{g}$ of soluble proteins was loaded per lane. Arrows indicate the $42-\mathrm{kDa}$ protein band. 
(four with very reduced vigor, five with intermediate vigor, and one with normal vigor) were further analyzed for lignin deposition and induction of POD and GLU activities (Table 4). Results indicated a significant positive correlation $(R=0.84 ; P<0.01)$ between POD and GLU activities. All tested lines with very reduced vigor (20-5, 20-7, 31-43, and 31-41) exhibited high level of POD activity (ranging from 17- to 43-fold control Ariane), high GLU activity (ranging from four to eightfold control) and lignin content. The line 31-29 with normal vigor did not show any significant increase of POD, GLU, or lignin deposition.

Scab resistance. Transgenic lines of normal vigor and their control lines, Galaxy and Ariane, were inoculated in a growth chamber with race 1 or race 6 of $V$. inaequalis. When inoculated with the race 1 , two of the nine transgenic Galaxy lines exhibited a significant reduction of susceptibility (Table 2). When inoculated with the race 6 , one transgenic line (32-19) exhibited a significant reduction of susceptibility. The susceptibility of transgenic Galaxy lines toward the two races was significantly correlated $(R=0.79 ; P<0.01)$. Inoculation of transgenic and nontransgenic Ariane lines with race 1 of $V$. inaequalis resulted in resistance for all lines tested. Only symptoms of class 1 and class 2 were observed (data not shown). These phenotypes are frequently observed in case of resistance conferred by the $V f$ gene. The growth chamber inoculation of Ariane with race 6 (Table 3), which overcomes the resistance carried by the $V f$ gene, revealed high disease severity in the nontransgenic control (note of global disease severity of 4); four of the five transgenic lines tested exhibited a significant reduction in disease susceptibility.

When the overall results of these scab inoculations were considered according to incidence and severity parameters, the following trends appeared (Fig. 5). In general, incidence and severity were highly correlated $(R=0.75 ; P<0.01)$. On average, Ariane lines had a higher incidence (84\%) and severity (3.15) than that of Galaxy lines. Incidence of Galaxy lines was slightly higher with race $1(83 \%)$ than race $6(78 \%)$, whereas severity was very similar with race 6 (2.65) and race 1 (2.53). Among the six transgenic lines that differed significantly from their controls, five (32-19, 34-3, 36-3, 31-54, and 31-29) expressed a reduction in both incidence and severity of their symptoms.

About $50 \%$ of the transgenic lines had a very limited growth in greenhouse, which prevented the assessment of their scab susceptibility. Hence, a scab bioassay on in vitro rooted shoots was developed. Preliminary experiments indicated that inoculation of nonrooted in vitro shoots resulted in atypical apple scab symptoms, identical to the development of a superficial mycelium (data not shown). Two transgenic lines of Galaxy with reduced vigor were tested for their resistance to race 1: line 32-9 with low endochitinase activity and line 34-6 with high endochitinase activity. A significant resistance was noticed only for line 34-6 (data not shown). A sample of 10 transgenic lines from Ariane (seven with very reduced vigor, two with moderate vigor, and one with normal vigor) was tested with race 6 using this in vitro bioassay. Among the four lines that were tested both on acclimatized and on in vitro plants, a high positive correlation between resistance of lines tested in vitro and in greenhouse was observed, thus confirming the validity of this simplified bioassay. All transgenic lines with reduced vigor exhibited significantly reduced scab symptoms in vitro compared with that of nontransgenic Ariane. Results also indicated a significant negative correlation between endochitinase activity and disease severity $(R=-0.80$; $P<0.01)$.
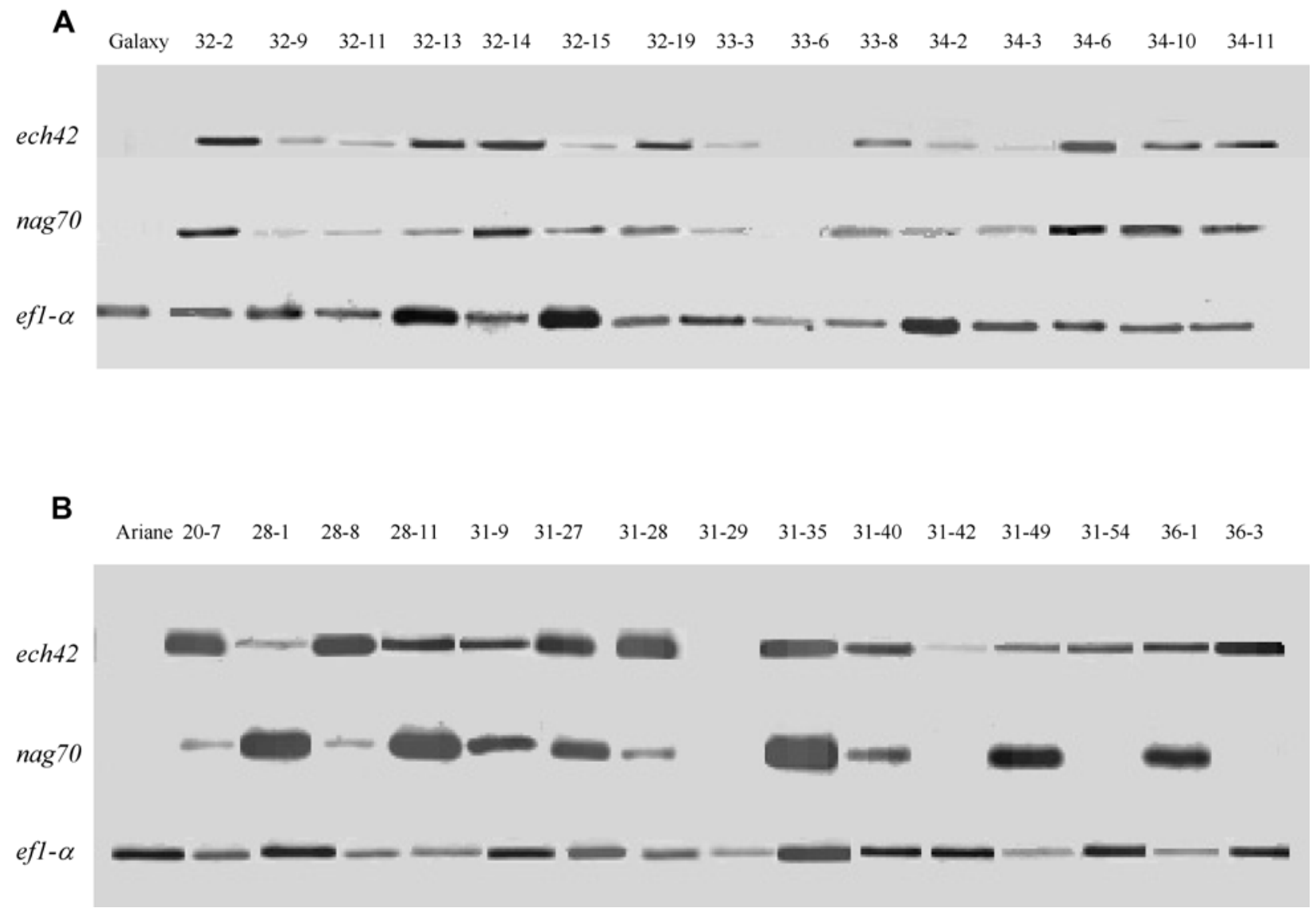

Fig. 3. Steady-state level of ech 42 and nag70 gene transcripts in leaves of nontransgenic and transgenic lines from A, Galaxy and B, Ariane. Semiquantitative reverse transcription-polymerase chain reaction analyses were performed on total RNA extracted from leaf tissue. The size of the amplicon of ech42 gene transcript was 1,000 bp and the size of the amplicon of nag70 gene transcript was $700 \mathrm{bp}$. The size of the amplicon of efl- $\alpha$, which was used as a constitutive control, was $700 \mathrm{bp}$. 


\section{DISCUSSION}

In this study, we evaluated the use of transgenic defense genes of T. atroviride (endo- and exochitinase genes ech42 and nag70, respectively) in combination with the natural $V f$ resistance gene to enhance apple disease resistance against $V$. inaequalis. The strategy of gene pyramiding has been proposed to achieve long-lasting resistance by reducing the likelihood of the breakdown of the resistance by the pathogens in conventional breeding programs (43) as well as in genetic engineering (37). In the case of apple scab, new races of the pathogen have already overcome the resistance conferred by the $V f$ gene, which is widely used to enhance apple scab resistance $(34,38)$. In addition to susceptible apple cv. Galaxy, we have thus transformed resistant hybrid Ariane with $T$. atroviride chitinase genes. 'Ariane' was bred by introgression of the $V f$ gene for scab resistance from the crab apple $M$. floribunda into Malus $\times$ domestica. Transformation of apple with these transgenes recently has been reported (2) but only on very susceptible cv. McIntosh.

Fourty transgenic lines were generated in this study. They expressed the endochitinase activity alone or the endochitinase plus exochitinase activities but none of them expressed only a high exochitinase activity. Our results showed that the percentage of transgenic lines expressing high endochitinase or exochitinase

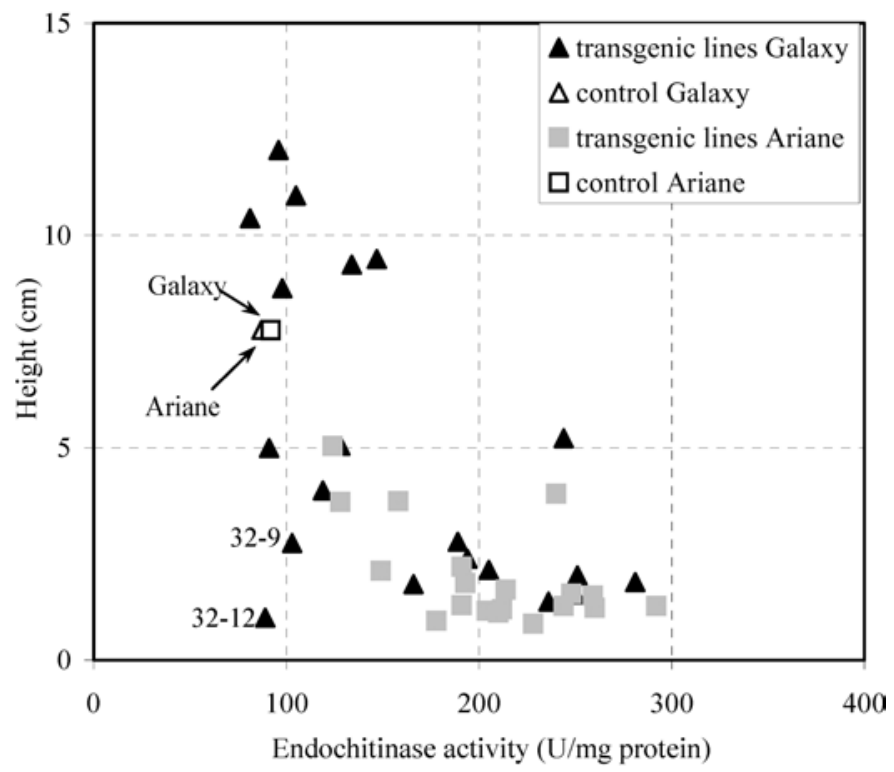

Fig. 4. Effect of level of endochitinase expression on the height of transgenic lines and their controls.

TABLE 4. Peroxidase (POD) and glucanase (GLU) activities and lignin deposition in transgenic lines of Ariane ${ }^{\mathrm{a}}$

\begin{tabular}{lcccc}
\hline Line & $\begin{array}{c}\text { Height } \\
(\mathrm{cm})\end{array}$ & $\begin{array}{c}\text { POD activity } \\
(\mathrm{nmol} / \mathrm{min} / \mathrm{mg} \text { of protein })\end{array}$ & $\begin{array}{c}\text { GLU activity } \\
\text { (U/mg of protein) }\end{array}$ & $\begin{array}{c}\text { Lignin } \\
\text { deposition }\end{array}$ \\
\hline Ariane & 7.76 & $9 \pm 4$ & $12 \pm 2$ & - \\
$31-29$ & 5.05 & $14 \pm 7$ & $17 \pm 7$ & - \\
$36-3$ & 3.93 & $24 \pm 2$ & $15 \pm 13$ & + \\
$28-1$ & 3.75 & $13 \pm 3$ & $17 \pm 10$ & - \\
$31-42$ & 3.73 & $11 \pm 8$ & $10 \pm 3$ & - \\
$31-49$ & 2.20 & $27 \pm 6$ & $20 \pm 8$ & + \\
$31-54$ & 2.11 & $5 \pm 3$ & $10 \pm 5$ & - \\
$31-41$ & 1.66 & $384 \pm 71^{*}$ & $72 \pm 19^{*}$ & ++ \\
$31-43$ & 1.20 & $150 \pm 39^{*}$ & $51 \pm 30^{*}$ & +++ \\
$20-7$ & 1.17 & $150 \pm 60^{*}$ & $91 \pm 9^{*}$ & +++ \\
$20-5$ & 0.86 & $344 \pm 110^{*}$ & $74 \pm 13^{*}$ & +++ \\
\hline
\end{tabular}

a $*$ Indicates transgenic lines significantly different from the control Ariane at $P<0.05$ according to Dunnett's test.

${ }^{b}$ Data are the mean of four replicates \pm confidence interval at $\alpha=5 \%$.

${ }^{c}$ Intensity of red on qualitative scale. activities was two times greater among lines derived from Ariane than from Galaxy, whereas the background chitinase activity of both cultivars was similar. This difference indicates a possible effect of the genetic background on transgene expression. A strong correlation between the enzymatic activity of endochitinase and the intensity of this protein revealed by western blot analysis was observed, irrespective of the genotype. Such a correlation also has been reported on very susceptible cv. McIntosh (3). However, in Bolar et al. (3), the increase of endochitinase activity in the transgenic lines was much greater $(5,000$-fold the activity of the control) than that observed in our study (threefold the activity of the controls). A possible explanation lies in the difference of sensitivity between the techniques used in both studies (colorimetric versus fluorometric assay). Concerning exochitinase, we did not use western blot to detect this protein because we lacked the antibody anti-exochitinase. However, two different techniques were used for enzymatic assay of exochitinase activity, with similar patterns of results (data not shown). Furthermore, a correlation was noticed between the relative quantities of mRNA transcribed from the two transgenes and the corresponding enzymatic activities. Throughout this study, the overall molecular and biochemical data describing the expression of the transgenes were consistent.

About half of the transgenic lines exhibited reduced vigor ex vitro, and a negative correlation between vigor and endochitinase activity was observed. This reduction of vigor seemed to be more pronounced in the transgenic lines from resistant hybrid Ariane. It also has been reported in very susceptible cv. McIntosh transformed with endochitinase transgene (3), but never explained. Our results clearly showed that some transgenic lines of Ariane expressed a high level of endochitinase activity along with high lignin content, which may provide cell with a rigid wall, thus reducing their extensibility. They also expressed significantly higher POD activities. POD is required for the final polymerization of phenol derivatives into lignin. Similar observations were made on other transgenic woody plants. Antisense expression of a POD gene in transgenic aspen resulted in repression of lignin and improvement of their growth (16) and overexpression of POD-like

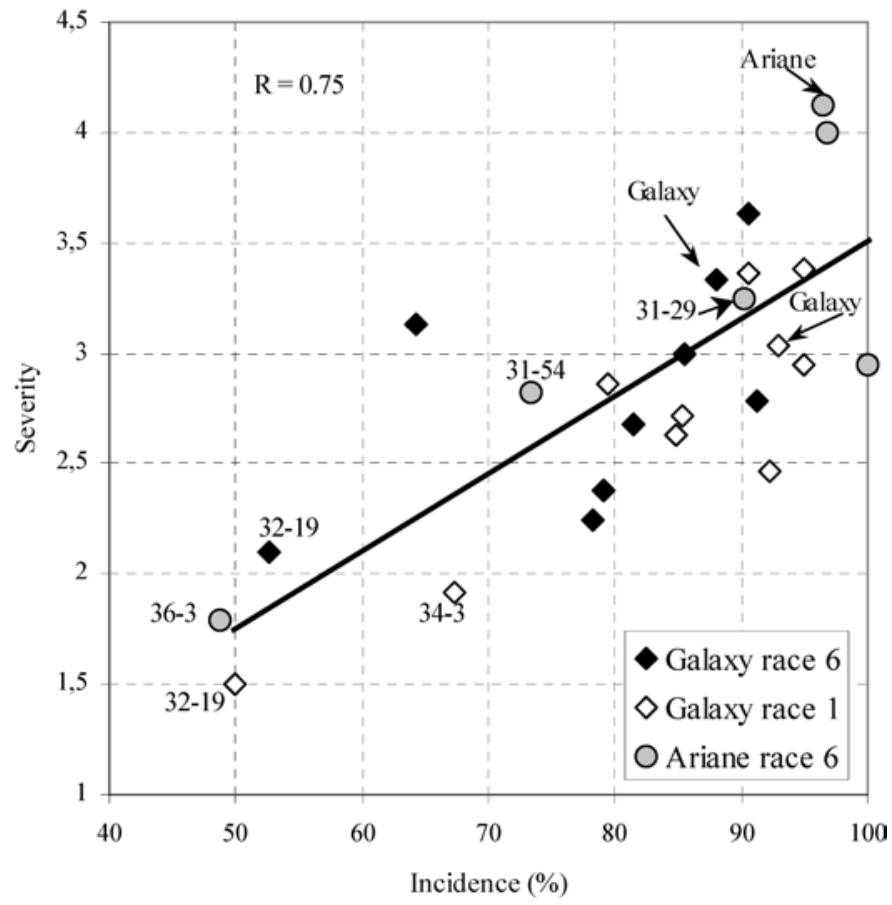

Fig. 5. Relationship between incidence and severity of scab symptoms scored on greenhouse-grown plants from transgenic and nontransgenic Galaxy and Ariane lines after inoculation with races 1 and 6 of Venturia inaequalis. 
spi 2 gene increased POD activity, reduced growth of transgenic Norway spruce plants, and caused a deeper phloroglucinol staining (10). Our results also indicated that transgenic lines of very reduced vigor exhibited high GLU activities. GLU are known as antifungal proteins that are induced during infection and disease resistance. One hypothesis that may explain this observation is that endochitinase of $T$. atroviride may act on the plant by releasing elicitors of defense responses, inducing modification in the phenol metabolic pathway and synthesis of PR proteins. These results suggest that the expression of ech42 gene of $T$. atroviride modifies the metabolism of apple. Furthermore, when micrografted on the rootstock MM106, transgenic lines with reduced vigor expressed a partial recovery of their growth ability in greenhouse (data not shown), indicating that the inhibition of growth could be explained partly by a hormonal imbalance resulting in underdeveloped root system.

In this study, the two genotypes and their derivative transgenic lines were inoculated with two races of $V$. inaequalis: common race 1 and race 6 which overcomes resistance conferred by the $V f$ gene of cv. Ariane. Growth chamber inoculations were performed on lines of sufficient vigor. When inoculated with race 6 , nontransgenic Ariane exhibited higher disease susceptibility than that of nontransgenic Galaxy. This could be explained by the different genetic backgrounds of the two cultivars. Among transgenic lines of sufficient vigor, scab susceptibility was significantly reduced in four lines from Ariane (challenged with race 6) and two lines from Galaxy (challenged with race 1). The highest degree of symptom reduction (50 to $80 \%$ ) was observed in lines that also expressed the highest endochitinase activity (32-19 and 36-3). To evaluate resistance of transgenic lines with reduced vigor, we developed a bioassay based on inoculation of in vitro rooted shoots. We confirmed that rooting of in vitro shoots prior to scab inoculation was necessary to produce all typical symptoms of scab disease exhibited ex vitro as previously described by Guillaumès et al. (12). Furthermore, the presence or absence of scab symptoms was confirmed by counting conidia recovered from leaf tissues (data not shown). We also verified that endochitinase and/or exochitinase activities were similar in in vitro and acclimatized shoots (data not shown). However, disease severity was generally lower in rooted in vitro shoots than in acclimatized plants, which could be explained by differences in the structure of the cuticula: reduced amount of epicuticular wax and numerous nonfunctioning stomata (36). Overall results from the in vitro bioassay showed that all tested lines of reduced vigor with high endochitinase activity exhibited reduction of apple scab symptoms ranging from 30 to $80 \%$.

We cannot exclude that part of the increased resistance of the transgenic lines could be explained by somaclonal variation due to regeneration or transformation events. One of the Galaxy lines of a reduced vigor (32-9) was probably a somaclonal variant, because it did not express any significant chitinase activity. However, no reduction of scab susceptibility (in vitro assessment) could be measured with this line (data not shown).

In conclusion, the transfer of chitinase genes of $T$. atroviride in apple resulted in different levels of transgene expression and scab resistance according to the transformed genotype and to the strain of $V$. inaequalis tested. Our results also suggest that the presence of high endochitinase level prior to infection may have triggered some of the host defense mechanisms, thus contributing to the reduction of disease susceptibility of apple. A complementary scab resistance test on a sample of 12 transgenic lines from 'Gala' carrying only the $\beta$-glucuronidase marker gene (uidA) showed no significant increase of resistance among these lines (data not shown), thus indicating a very limited range of somaclonal variation for scab resistance in transgenic apple lines. In order to formally demonstrate the role of the transgene in the observed resistance, further studies are needed to investigate the cosegregation of the presence of the transgene and the resistant phenotype in a progeny from the transgenic plants. In several transgenic lines from both genotypes, high endochitinase level was associated with a severe growth reduction. Therefore, the effect of endochitinase on scab resistance could not be evaluated independently from their effect on plant growth. This detrimental impact of T. atroviride endochitinase expression in apple could be limited by the use of a more specific (e.g., pathogen-inducible) promoter. Recent results on pear (28) indicate that tobacco promoters str246C or $s g d 24$ could be suitable candidates to drive the expression of transgenes for disease resistance. Although field studies of the transgenic lines will be necessary to further evaluate scab resistance on fruit and other agronomical traits, our results indicate that the combination of defense transgene with a major gene such as $V f$ gene is an attractive strategy to protect apple from strains of $V$. inaequalis carrying various virulences.

\section{ACKNOWLEDGMENTS}

This work was supported by a postdoctoral fellowship from INRA (M. Faize) and a partial funding from the "Region Pays de Loire" and the Ministry of Agriculture (CTPS). We thank H. S. Aldwinckle (Cornell University, New York) for providing the pBIN (Endo+Nag) construct, G. E. Harman (Cornell University) for providing antiserum anti-ech42, and F. Didelot, S. Gabard, J. Gaudin, L. Leclout, and C. Ortolan for excellent technical assistance.

\section{LITERATURE CITED}

1. Bénaouf, G., and Parisi, L. 2000. Genetics of host-pathogen relationships between Venturia inaequalis races 6 and 7 and Malus species. Phytopathology 90:236-242.

2. Bolar, J. P., Norelli, J. L., Harman, G. E., Brown, S. K., and Aldwinckle, H. S. 2001. Synergistic activity of endochitinase and exochitinase from Trichoderma atroviride (T. harzianum) against the pathogenic fungus (Venturia inaequalis) in transgenic apple plants. Transgenic Res. 10:533543.

3. Bolar, J. P., Norelli, J. L., Wong, K. W., Hayes, C. K., Harman, G. E., and Aldwinckle, H. S. 2000. Expression of endochitinase from Trichoderma harzianum in transgenic apple increases resistance to scab and reduces vigor. Phytopathology 90:72-77.

4. Bradford, M. M. 1976. A rapid and sensitive method for quantification of microgram quantities of proteins utilizing the principle of protein-dye binding. Anal. Biochem. 72:248-254.

5. Brown, S. C., Bergounioux, C., Tellet, S., and Marie, D. 1991. Flow cytometry of nuclei for ploidy and cell cycle analysis. Pages 326-345 in: A Laboratory Guide for Cellular and Molecular Plant Biology. I. Negrutiu and G. B. Gharti-Chhetri, eds. Birkhauser Verlag, Basel.

6. Chevalier, M., Lespinasse, Y., and Renaudin, S. 1991. A microscopic study of different classes of symptoms coded by the $V f$ gene in apple resistance to scab (Venturia inaequalis). Plant Pathol. 40:249-256.

7. Datta, K., Muthukrishnan, S., and Datta, S. K. 1999. Expression and function of PR-protein genes in transgenic plants. Pages 261-277 in: Pathogenesis-Related Proteins in Plants. S. K. Datta and S. Muthukrishnan, eds. CRC Press, Boca Raton, FL.

8. De Bondt, A., Zaman, S., Broekaert, W., Cammue, B., and Keulemans, J. 1999. Genetic transformation of apple (Malus pumila Mill.) for increased fungal resistance: In vitro antifungal activity of protein extracts of transgenic apple expressing RS-AFP2 or ACE-AMP1. Acta Hortic. 484:565-570.

9. Doyle, J. J., and Doyle, J. L. 1990. Isolation of plant DNA from fresh tissue. Focus 12:13-15.

10. Elfstrand, M., Fossdal, C. G., Sitbon, F., Olsson, O., Lönneborg, A., and Arnold, S. V. 2001. Overexpression of the endogenous peroxidase-like gene spi 2 in transgenic Norway spruce plants results in increased total peroxidase activity and reduced growth. Plant Cell Rep. 20:596-603.

11. Gongora, C. E., and Broadway, R. M. 2002. Plant growth and development influenced by transgenic insertion of bacterial chitinolytic enzymes. Mol. Breed. 9:123-135.

12. Guillaumès, J., Chevalier, M., and Parisi, L. 1995. Etude des relations Venturia inaequalis-Malus $\times$ domestica sur vitroplantes. Can. J. Plant Pathol. 17:305-311.

13. Gurr, E. 1965. Rational Use of Dyes in Biology. Williams \& Wilkins, Baltimore, MD.

14. Harman, G. E., Hayes, C. K., Lorito, M., Broadway, R. M., Di Pietro, A., Peterbauer, C., and Tronsmo, A. 1993. Chitinolytic enzymes of Trichoderma harzianum: Purification of chitobiosidase and endochitinase. Phytopathology 83:313-318. 
15. Hood, E. E., Gelvin, S. B., Melchers, L., and Hoekema, A. 1993. New Agrobacterium helper plasmids for gene transfer to plants. Transgenic Res. 2:208-218.

16. Hu, W. J., Harding, S. A., Lung, J., Popko, J. L., Ralph, J., Stokke, D. D., Tsai, C. J., and Chiang, V. L. 1999. Repression of lignin biosynthesis promotes cellulose accumulation and growth in transgenic trees. Nat. Biotechnol. 17:808-812.

17. Jefferson, R. A., Kavanagh, T. A., and Bevan, M. W. 1987. Gus gene fusions: $\beta$-Glucuronidase as a sensitive and versatile gene fusion marker in higher plants. EMBO J. 6:3901-3907.

18. Kikkert, J. R., Ali, G. S., Wallace, P. G., Reisch, B., and Reustle, G. M. 2000. Expression of a fungal chitinase in Vitis vinifera L. 'Merlot' and 'Chardonnay' plants produced by biolistic transformation. Acta Hortic. 528:297-303.

19. Koller, W., Wilcox, W. F., Barnard, J., Jones, A. L., and Braun, P. G. 1997. Detection and quantification of resistance of Venturia inaequalis populations to sterol demethylation inhibitors. Phytopathology 87:184190.

20. Laemmli, U. 1970. Cleavage of structural proteins during the assembly of bacteriophage T4. Nature (Lond.) 227:680-685.

21. Laurens, F. 1998. Review of the current apple breeding programmes in the world: Objectives for scion cultivar improvements. Acta Hortic. 484:163-170.

22. Lespinasse, Y., Durel, C. E., Parisi, L., Laurens, F., Chevalier, M., and Pinet, C. 2000. A European project D.A.R.E.-Durable Apple Resistance in Europe-one step towards an environmental friendly orchard. Acta Hortic. 583:197-200.

23. Lorito, M., Harman, G. E., Hayes, C. K., Broadway, R. M., Tronsmo, A., Woo, S. L., and Di Pietro, A. 1993. Chitinolytic enzymes produced by Trichoderma harzianum: Antifungal activity of purified endochitinase and chitobiosidase. Phytopathology 83:302-307.

24. Lorito, M., Hayes, C. K., Di Pietro, A., Woo, S. L., and Harman, G. E. 1994. Purification, characterization, and synergistic activity of a glucan 1,3- $\beta$-glucosidase and an $N$-acetyl- $\beta$-glucosaminidase from Trichoderma harzianum. Phytopathology 84:398-405.

25. Lorito, M., Woo, S. L., Fernandez, I. G., Colucci, G., Harman, G. E., Pintor, T. J. A., Filippone, E., Muccifora, S., Lawrence, C. B., Zoina, A., Tuzun, S., and Scala, F. 1998. Genes from mycoparasitic fungi as a source for improving plant resistance to fungal pathogens. Proc. Natl. Acad. Sci. USA 95:7860-7865.

26. MacHardy, W. E. 1996. Apple Scab: Biology, Epidemiology, and Management. The American Phytopathological Society, St. Paul, MN.

27. Mahe, A., Grisvard, J., and Dron, M. 1992. Fungal and specific gene markers to follow the bean-anthracnose infection process and normalize the bean chitinase mRNA induction. Mol. Plant-Microbe Interact. 5:242248.

28. Malnoy, M., Venisse, J.-S., Reynoird J.-P., and Chevreau, E. 2003. Activation of three pathogen-inducible promoters of tobacco in transgenic pear (Pyrus communis L.) after abiotic and biotic elicitation. Planta 216:802-814.
29. Moerschbacher, B., Heck, B., Kogel, K. H., Obst, O., and Reisener, H. G. 1986. An elicitor of the hypersensitive lignification response in wheat leaves isolated from the rust fungus Puccinia graminis f. sp. tritici. II. Induction of enzymes correlated with the biosynthesis of lignin. Z . Naturforsch. 41c:839-844.

30. Mora, A. A., and Earle, E. D. 2001. Resistance to Alternaria brassicola in transgenic brocoli expressing a Trichoderma harzianum endochitinase gene. Mol. Breed. 8:1-9.

31. Norelli, J., Mills, J. A., and Aldwinckle, H. S. 1996. Leaf wounding increases efficiency of Agrobacterium-mediated transformation of apple. HortScience 31:1026-1027.

32. Parisi, L., Durel, C. E., and Laurens, F. 2000. First report on the presence of Venturia inaequalis race 7 in French apple orchards. IOBS/WPRS Bull. 23:99-104.

33. Parisi, L., and Lespinasse, Y. 1996. Pathogenicity of Venturia inaequalis strains of race 6 on apple clone (Malus sp.). Plant Dis. 80:1179-1183.

34. Parisi, L., Lespinasse, Y., Guillaumès, J., and Krüger, J. 1993. A new race of $V$. inaequalis virulent to apples with resistance due to the $V f$ gene. Phytopathology 83:533-537.

35. Patil, V. R., and Widholm, J. M. 1997. Possible correlation between increased vigor and chitinase activity expression in tobacco. J. Exp. Bot. 48:1943-1950.

36. Preece, J. E., and Sutter, E. G. 1991. Acclimatization of micropropagated plants to the greenhouse and field. Pages 71-93 in: Micropropagation. P. C. Debergh and R. H. Zimmerman, eds. Kluwer Academic Publishers, Dordrecht, the Netherlands.

37. Punja, Z. K. 2001. Genetic engineering of plants to enhance resistance to fungal pathogens-A review of progress and future prospects. Can. J. Plant Pathol. 23:216-235.

38. Roberts, A. L., and Crute, I. R. 1994. Apple scab resistance from Malus floribunda 821 (Vf) is rendered ineffective by isolates of Venturia inaequalis from Malus floribunda. Norw. J. Agric. Sci. 17:403-406.

39. Rosati, C., Cadic, A., Duron, M., Renou, J. P., and Simoneau, P. 1997. Molecular cloning and expression analysis of dihydroflovanol 4-reductase gene in flower organs of Forsythia $\times$ intermedia. Plant Mol. Biol. 15:303-311.

40. Sahai, A. S., and Manocha, M. S. 1993. Chitinases of fungi and plants: Their involvement in morphogenesis and host-parasite interaction. FEMS Microbiol. Rev. 11:317-338.

41. Shuster, A. M., and Davies, E. 1983. Ribonucleic acid and protein metabolism in pea hypocotyl. I: The aging process. Plant Physiol. 73:809-813.

42. Valentine, B. 1995. 'Galaxy'. Plant Var. J. 8:6.

43. Wenzel, G. 1985. Strategies in unconventional breeding for disease resistance. Annu. Rev. Phytopathol. 23:149-172.

44. Wirth, S. J., and Wolf, G. A. 1992. Micro-plate colorimetric assay for endo-acting cellulase, xylanase, chitinase, 1,3- $\beta$-glucanase and amylase extracted from forest soil horizons. Soil Biol. Biochem. 24:511-519.

45. Wong, K. W., Harman, G. E., Norelli, J. L., Gustafson, H. L., and Aldwinckle, H. S. 1999. Chitinase-transgenic lines of "Royal Gala" apple showing enhanced resistance to apple scab. Acta Hortic. 489:595-599. 